\title{
Revealing Theme of The Road Not Taken by Robert Frost
}

\author{
Sri Mulyati \\ Universitas Bina Sarana Informatika \\ sri.smq@bsi.ac.id

\begin{tabular}{ccc}
\hline Diterima & Direvisi & Disetujui \\
$22-01-2021$ & $24-03-2021$ & $25-03-2021$ \\
\hline
\end{tabular}

\begin{abstract}
The writer analyzed a poetry entitled "The Road Not Taken" by Robert Frost. The purpose of this analysis is to show analysis result that are limited to the theme of the lyrick. For further analysis, the writer uses a qualitative approach as a research methodology. While for analyzing the theme, the writer uses descriptive method as methodological research that reveals the data in each stanza trough revealing each line of the poetry. The result of the analysis is the theme of this poetry describes about deep regretting for the life choice that speaker made. The speaker faced between which of two roads to take, that is the two divergent roads (life choices). The speaker didn't know sure whether the choice is the right one, because it was made with incomplete informatios. Then in the end of the poetry, the speaker told about deep regrett and a hope that he could try a road had not been taken, so that his life was better, but he couldn't. Even finally, the choice he made got him died.
\end{abstract}

Keywords : literature, poetry, theme

Abstrak - Penulis menganalisa sebuah puisi berjudul "The Road Not Taken" karya Robert Frost. Analisis ini bertujuan untuk menunjukkan hasil analisis yang dibatasi pada tema lagu. Untuk analisis lebih lanjut, penulis menggunakan pendekatan kualitatif sebagai metodologi penelitian. Sedangkan untuk menganalisis tema, penulis menggunakan metode deskriptif sebagai penelitian metodologis yang mengungkap data pada setiap bait melalui pengungkapan setiap baris puisi. Hasil analisis menunjukkan bahwa puisi ini mengangkat tema tentang penyesalan yang mendalam atas pilihan hidup yang dibuat oleh pembicara. Pelaku dihadapkan di antara dua jalan yang harus diambil, yaitu dua jalan yang berbeda (pilihan hidup). Pelaku tidak tahu pasti apakah pilihannya tepat, karena dibuat dengan informasi yang tidak lengkap. Kemudian di akhir puisi, pelaku bercerita tentang penyesalannya yang teramat dalam dan berharap bisa mencoba jalan yang belum dilaluinya, agar hidupnya lebih baik, tetapi ia tidak bisa. Bahkan akhirnya, keputusan yang dipilih membuatnya wafat.

Kata kunci : sastra, puisi, tema

\section{INTRODUCTION}

Talking about literature, it cannot be separated from humans life. Literature is born through the expression of human expression, and society itself will judge the presence of this literature. Literature work has literary value in which there is a correspondence between form and content. Literature is expression of artistic and imaginative facts as manifestation human life through language as the media. Literature is a form of creative imaginatioan used to express ideas, thoughts, and feelings of a poet in a beautiful specific way. Just as this opinion "Literature is an art that used language and other signs as a tool and imaginative". (ahmad badrun:1983;16). By this definition can be concluded that literature is art created by human uses language and siymbos to convey author means to the readers

Literature is art used to describe written or spoken material or anything from creative writing to more technical or scientific works. With literature, human can depict and explore their imaginations, emotional, experiences, and ideas through fiction or non fiction works. Such as poetry, poem, lyric of songs, film, and or drama. Written form is one of literary works presents with a specific form and with a choice of beautiful words and well structured. Poetry is one of written works contains language with aesthetic qualities and has specific meaning inside. Poetry can be an outpouring of someone's heart and written in meaningful beautiful words. Poetry can contain single words or syllables that are repeated continuously.

However, before the selection of the beautiful words formed into poetry, a poet should determine the theme first. Because the theme is the main idea to develop a poetry. This main idea will then develop trough the explanations and relationship of each word in the poetry. From this theme, it will become a framework for the development of the poetry. 
Every written works or discussion has a point of thought or discussion. This point of thought or subject matter will be the basic idea in writing. Thus, the writing will not deviate from the predetermined purpose. This basic thought or idea is called a theme. On the other words, theme is the base step for a poet develop poetry. Theme is also determine the words choice that poet will use in developing poetry. If the theme is about love, the words choice used is also about love.

The existence of a theme is very important for determining whether the poetry is good or not. With a theme, a poet knows what he wants to write about. For that reason, the theme must be presented as well as possible so that the reader can more easily understand the author's intent and purpose. The word 'theme' comes from Greek which mean 'to place' or' to put' according to the meaning of the word 'something that has been depicted' or' something that has been placed. Keraf opines that "A theme is a formulation and topic that will be used as a basis for discussion and objectives to be achieved through the topic." The topic or subject of this discussion puts a goal to be conveyed by the author. By stating the topic, it means that the author has stated the intent and purpose of the conversation. (Keraf, 1994:107108). By the above opinion, it can be concluded that theme is poet meant conveyed trough words order to develop poetry. Theme as the base element determines the result of the poetry. Edward Arlington Robinson in Beach and Marshall (1991: 389) explains that the content contained in poetry is the poet's emotional reaction which is displayed through language. This emotional reaction is poured through the words that have been arranged as attractive as possible to form a series of lyrics that represent the feelings of the poet. According to the above opinion, it can be concluded that the content of poetry is poet's emotional expression which describes through words. The words order put in specific way as beautiful as possible that represent poet's feelings or imaginations.

Finoza emphasizes that a theme is the main thought, idea, or idea that will become the background and encourage someone to write their essay. Thus, if someone thinks about something or determines a theme, of course there is a certain purpose or objective. This is what underlies the background (intent, objective, target) written into his writing. (Finoza, 2008:215). From above opinion, it meants that theme is the main idea which will becoma the basic of the poetry to stimulate poet to write his idea with certain intention. Theme is like a way that directs a poet to pour chosen words becoma poetry. Related to the theme as a central idea, Baribin in Wahyuningtyas and Santosa explain that a theme is a central idea, something to be fought for in a writing or a work of fiction. It is clear that the theme is the main idea or central idea of the author in the work he makes based on the goals the poet or writer wants to convey. ( Baribin and Santosa, 2011: 2-3). It means that a theme consists of a number of ideas or groups of ideas embodied in a work. Thus, themes can not only be assembled through a series of words, but groups of ideas or groups of ideas that support the objectives of the discussion. This is done so that the theme becomes and more alive. With a good theme, it will reflect the views or thoughts of the author. With a theme, it is easier for readers to grasp the idea or group of ideas the writer wants to convey.

Poetry consists of lines and stanzas with chosen words, emphasizes the harmony of the sounds of the language and the equivalence of the sounds. The difference between poem and poetry is only in form. Poetry can be an outpouring of someone's heart and written in meaningful beautiful words. Poetry can contain single words or syllables that are repeated continuously. Knickerboker \& Reninger, (1963; 307) says that "poetry is the hymn of praise". Good talk about poetry is nevertheless rare and even the best of it will rest on fallow ground until we ourselves have learned how to penetrate the inner life of a few poem". By above opinion can be concluded that poetry is a media that not only to express the feeling of the poets but also to make us get into these feelings about the things, persons, situations or ideas in the poem.

According to Reed (1946:92) in Barnet, Berman, and Burto (1961); "poetry is attempts to put into words feelings and thoughts. Poetry also attempts to do this in a manner which will make a memorable impression; it uses memory, devices, and ideas, such as figure of speech, rhyme, and rhythme. Poetry was chosen either because of its documentary importance for a full understanding of the periods and the works of the majors poets because of its intrinsic excellence. It means that poetry is describing feelings, reactions, and attitude of the writer about daily life of human beings or poetry can also talk about the fact of social life which will make a memorable impression". According to Landy (1984:413), states that poetry is musical or at least rhythmic speech. It is also usually a harmonious speech employing words whose sounds echo each other or blend well. It may even be set to music, to be chanted or sung rather than simply spoken. By this definition, it means that poetry is words composition that ordered with rhyming lines, implying ideas, and its meaning has connection each other. It is also can be ordered in a song. And it will much easier to be remembered by the readers rather than a paragraph on textbook or other sources.

Poetry and poem are different than other types of literary works. They are not only has characteristic which makes them different than ordinary speech or writing, but also the rhythm is unique, and there is 
beauty in it. Poetry is a form of spontaneous overflowing creations of a poet in expressing his experiences, feelings, thoughts, or ideas through beautiful words which tend to have connotations.Poetry or poem are defined as a form of literary art evoked in language. It can be written on its own or in combination with other arts as poetic drama, lyrical poetry, and prose poetry. Poem is the arrangements of words contain meaning and musically elements. It is a piece of writing expresses poet's thought in order to set a mood. It can be happy or sad, simple or complex.

\section{RESEARCH METHODOLOGY}

\section{Approch of the Study}

In doing research, the writer uses qualitative approach as approach of research methodology. Qualitative approach used because this approach describes and provides the assumption and procedures used detail. Qualitative approach is the method which does not use statistic data. It is associated to hypothesis generating and developing an understanding. This approach will make this research get deeper information and will be easy to collect the data. "Qualitative methods (or approaches) the human and social sciences offer several traditions. These traditions may be method types for data collection analysis, and reporting writing, or overall designs that include all phases in the research process". (Creswell, 1944) Based on the definition above that qualitative method is the human's view through observation that get the fact after analyzing, collecting, reporting, and writing in researching data

\section{Data Analysis}

In analyzing the data, the writer uses descriptive method. The aim of this method is to give a description of condition in a situation systematically, accurately, and factually. So, it will be easier to comprehend the meaning of the theme. Descriptive method is a method which is concise in order to get and to analyze data much easier that relate to the matter being studied. By using the descriptive method, the writer tries to find out the exact and enough description through process and object. Through this method the writer hopes the readers will get the real descriptions about theme in Robert Frost's poetry as well.

By revealing the data, the speaker will find its meaning in each line of every stanza of the poetry. So, the readers can understand more about what the poet means in the poetry. It is clearly that analyzing of the theme is one way to get the meaning of the poetry. It is also helps understanding what the poet wants to show to the readers. It can be used to find out the theme of the "The Road Not Taken" by Robert Lee Frost.

\section{FINDING AND RESULT}

\section{Robert Lee Frost}

Robert Lee frost was an American famous poet and was honored frequently during his lifetime. $\mathrm{He}$ is the only poet who received four 'Pulitzer Prizes'. It is the highly regarded award in the field of print out journalism in the United States. This award is also given for achievements in the fields of literature and musically compositions. He was born in 1874 and died in 1963. He dedicated his life in literature field especially for poetry. "The road not taken" inspired from his friend's real story, Thomas Thompson.

Thomas and Frost became close friend and often went on walk together. After Frost returned to New Hampshire in 1995, he sent Thomas an early copy of "The Road Not Taken". Thomas took the poetry seriously and personally, and probably important in Thomas's decision to enlist in world war I. Then Thomas was killed two years later in the battle of Arras. Most of Robert Frost works use figurative language, such as metaphor, symbol, and irony. "The Road Not Taken" created in 1916. It is the most popular poetry of Frost. This poetry consists of four stanzas with five lines on each, with rhyme scheme $\mathrm{ABAAB}$ and uses open form. Usually strong emotion of love, sadness, anger, or admiration come to mind for most people. Most poetry and poem do focus on those intense emotions. However, there is much more to poetry than the subject matter. The form which is the structure and shape of a poetry, usually plays a crucial role. The crucial roles in poetry are stanza and form.

To reveal the theme, the best way to define is by revealing each stanza through each line. Because the author intentions are in them by using figurative language. The author composed this poetry uses many signs, that's why the meaning cannot be seen by the sentences or literally. The readers must interpret it through each line. In order to find the theme, the writer reveals each line on its stanza as described after this section. Furthermore, in this part the writer explains the data by revealing each line that help finding the theme of "The Road Not Taken" precisely. Following are the presentation of the descriptions.

\section{The Road not Taken poetry}

\section{The Road Not Taken}

Two roads diverged in a yellow wood, And sorry I could not travel both

And be one traveler, long I stood 
And looked down one as far as I could

To where it bent in the undergrowth;

Then took the other, as just as fair, And having perhaps the better claim, Because it was grassy and wanted wear; Though as for that the passing there Had worn them really about the same,

And both that morning equally lay In leaves no step had trodden black. Oh, I kept the first for another day! Yet knowing how way leads on to way, I doubted if I should ever come back.

I shall be telling this with a sigh Somewhere ages and ages hence: Two roads diverged in a wood, and II took the one less traveled by, And that has made all the difference.

\section{The Presentation of the Description}

Start from the first line, "Two roads diverged in a yellow wood". It means that the speaker describes himself faced between which of two roads to take. Two confusing choices in his life. The word road refers to human choice in life. People must make a choice.

But the speaker couldn't take both roads, he thought it was impossible to choose both. As in second line "And sorry I could not travel both". Then he took one of the roads (choices) and lived it alone. As in third line" And be one traveler, long I stood".

In forth line "And looked down one as far as I could", and fifth line "To where it bent in the undergrowth;". These lines tell that before the speaker decided to take one of the roads in front of him with incomplete information. He pondered for some time. He considered that both options were equally good and will end beautifully. He tried to conclude by himself that no one had ever experienced bad and he was sure that he could get through it. Then the speaker finally chose one of the roads as in sixth line "Then took the other, as just as fair". He thought that the choice he made was the right one to do.

The speaker hoped that his choice was the better one and he lived it, as in seventh line "And having perhaps the better claim". The choice was good and seemed want to be chosen by him, as in eighth line "Because it was grassy and wanted wear". He really thought that it was a choice that must be made because they were seemed equally good. As in ninth and tenth lines "Though as for that the passing there" and "Had worn them really about the same”.

The speaker thought that both roads were same and had good endings, since it seemed no one had passed on them yet. As in eleventh and twelve lines "And both that morning equally lay" and "In leaves no step had trodden black". It turned out that his estimate was completely wrong. He was really sorry and wanted to try the another one on other day. It tells in thirteenth line "Oh, I kept the first for another day!".

However, in regretting his choice along his time, the speaker also realized that it was too late and even he doubted about whether he could get recover or no. Those things are depicted in fourteenth and fifteenth lines; Yet knowing how way leads on to way" and "I doubted if I should ever come back".

The speaker regretted it deeply day by day along his journey, because the choice he took made him in a big trouble that he never wanted before. It tells in sixteenth line "I shall be telling this with a sigh". He always remembered, that years ago he faced a situation which brought him two face two roads (life choices). It tells in in seventeenth line "Somewhere ages and ages hence:" and there were two diverged roads (life choices), as in eighteenth line "Two roads diverged in a wood, and I- ".

Then the speaker took the one which seemed less travelled and thought it would have good ending. since he never heard bad news about it.as in nineteenth line" I took the one less traveled $b y$, ". But in the beginning of his life journey, he began realizes that the choice he made changed it all. He had just realized that it was completely wrong.

In a fact, his life journey didn't like he imagined before. It changed his mood in living his life. It made him became a man who always grumbling and blaming himself, also regretting every day. It tells in twentieth line "And that has made all the difference". The speaker regretted why he didn't take the other road (life choice). If he took the road which had not taken, he was sure he would be fine and happy. It tells in twentieth line.

Then the history tells that the speaker choice was about became a soldier and it forced him to involve himself in a world war $I$ in the battle of Arras. Finally, he died two years later in that war. This story caught the attention of most of people in US at that time. Even, the poetry is still become a famous poetry of Robert Frost.

\section{Theme of The Road Not Taken}


The theme of this poetry describes about speaker choice facing a choice between which of two roads to take. The two divergent roads. The roads here refer to life choices which had faced years ago by the speaker, Thomas Thompson. This poetry inspired by real life story of Thompson. The poetry makes clear that every choice involved the loss of opportunity and that choices are painful because they must be made with incomplete information.

The speaker tried to gather as much as information as possible by looking down one road as far as speaker could see, but there is a limit to what a speaker could see because the road is bent. It means that it curves, leaving the rest of it out of sight. So, the speaker like anyone faced with choices and must make a choice, but couldn't know enough to be sure with choice is the right one.

By making a choice, the speaker will never get the chance to experience the other road and can never which road less travelled. The speaker hides his psychic pain that he saved the first road for another day. The speaker thought that both choices were equally good.

This poetry ends with deep regret. The speaker imagined the far future when he thought back to these choices and believes that it made all the difference. At first, the speaker was sure that the choice he made was the better one and he started the journey alone. After a while, in the beginning of his journey, he realized that he had made a wrong choice. He deeply regretted it, since seemed no way out to try another road, that is the road which was not taken by him. Finally, his wish to went back to the beginning, it was just a dream and buried with himself who was killed at the battle of Arras. The poetry shows that making that choice doesn't actually solve the speaker's problem.

Although at first, this poetry had made a misunderstand to the readers but This history sticks strongly to the Us people's minds, moreover when they read this poetry. Immediately, their memories are carried over to the atmosphere experienced by the Thomas Thompson at that time.

\section{CONCLUSION}

First, this poetry describes about two divergent choices in speaker' life. The speaker had to take one of them. At first, the speaker thought that the choices were equally same, that is would have good endings. But, in a fact, the choice he made, didn't solve his problem. It even left deep regret and got him killed.

Second, there's must be choices that have to take by people in this life. The choice is to determine the next step in life. It's just that, sometimes the choices make us confused between to take both choices or one of them. Such that the person choosing will never know if they made the right choice.

Third, everyone must aware that every choice may be a beginning but it is also an ending. Every choice has risks. So, before deciding a thing or more, it must be thought wisely. We must imagine whether it will end good or not.

Some advices say that if we doubt about something we have to take, it would be better to not continue. Because usually it will get us to bad endings, such the speaker faced, as told in this poetry.

\section{REFERENCE}

S, M. Z. (n.d.) kurniawan, m. s. (n.d.). text analysis of poetry in hand book teacher. authentic assessment book publisher erlangga, 1-11.

(Mael, no date) Hidayat, R. (no date) 'ANALISIS PUISI DENGAN PENDEKATAN HERMENEUTIKA', pp. 61-68.

Mael, M. R. (no date) 'Analisis Lirik Lagu "Honjitsu wa Seiten Nari"'.

Mulyati, S.-. (2019). the Analysis of Five William Blake'S Poems. Wanastra: Jurnal Bahasa Dan Sastra, 11(2), 113-120. https://doi.org/10.31294/w.v11i2.5414

Prihantono, K. D., Bahasa, B., Jawa, P., Raya, J. E., \& Whitman, W. (2014). ANALISIS PENERJEMAHAN PUISI "I HEAR AMERICA SINGING " KARYA WALT WHITMAN : SEBUAH KAJIAN. 173-186.

Hidayat, R. (no date) 'ANALISIS PUISI DENGAN PENDEKATAN HERMENEUTIKA', pp. 6168.

Mael, M. R. (no date) 'Analisis Lirik Lagu "Honjitsu wa Seiten Nari”'.

Paper, A. (2007) The analyses of imagery, figurative language, and theme in modern english poetry.

'Syair al khansa sebuah analisa sastra $=$ Al khansa poetry an analytical literature' (no date), p. 20392695. 
Paper, A. (2007) The analyses of imagery, figurative language, and theme in modern english poetry.

Letters, F. O. F. (2015) 'The Image of Women in Lady Mary Chudleigh Poems: The Ladies , Defense and To the Ladies FACULTY OF LETTERS AND HUMANITIES'.

Adek, M. and Satria, D. (2020) "BIJAK DALAM KESEDERHANAAN": PENDAYAGUNAAN META- FORA DALAM PUISI INSTAGRAM (INSTA-POETRY)', 5(1), pp. 32-40. 